\title{
JUURNAL.RU
}

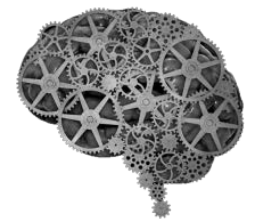

COMPANY GROUP "INTELLEKT"

\author{
Харабибер А.Э. \\ ГБОУ «Крымский инженерно-педагогический университет» \\ Симферополь, Россия
}

doi: 10.18411/lj2016-5-5-11

\section{Коннотация как способ хранения культурной информации}

Важной проблемой современной лингвистики является исследование способов хранения культурной информации. Культурная информация, по мнению Е.О. Опариной, может быть представлена в единицах языка четырьмя способами: через культурные семы, культурный фон, культурные концепты и культурные коннотации. «Культурные семы - способ отображения культуры в лексемах и фразеологизмах, обозначающих идиоэтнические реалии. Культурный фон - характеристика лексем и фразеологизмов, обозначающих явления социальной жизни и исторические события. К культурным концептам относятся имена абстрактных понятий, например: тоска', воля'». Ведущим способом хранения культурной информации современные лингвисты называют культурную коннотацию [6, с. 34].

Культурная коннотация - это в самом общем виде интерпретация денотативного или образно мотивированного, квазиденотативного, аспектов значения в категориях культуры. Применительно к единицам фразеологического состава языка как знакам вторичной номинации, характерной чертой которых является образно-ситуативная мотивированность, которая напрямую связана с мировидением автора - носителем языка, средостением культурной коннотации, ее основным нервом является это образное основание.

Согласно исследованиям В. Н. Телия, фразеологизмы возникают в национальных языках на основе такого образного представления 
действительности, которое, отображает обиходно-эмпирический, исторический или духовный опыт языкового коллектива, который безусловно связан с его культурными традициями, так как субъект номинации и речевой деятельности это всегда субъект национальной культуры [10, с. 215]. В этой связи уместно привести мнение Н. А. Бердяева о том, что каждый отдельный человек входит в человечество как национальный человек. Он писал: «Национальный человек больше, а не меньше, чем просто человек в нем есть родовые черты человека вообще и еще есть черты индивидуально-национальные» [10, с. 96]. Поэтому, по мнению Бердяева, и культуру всегда конкретно-человеческая, т.е. национальная.

По общепризнанному мнению, фразеологический состав языка представляет собой «наиболее самобытное его явление» не только в плане системно-регулярной анамальности, но в плане выражения фразеологизмами национальной самобытности народа - носителя языка [11, с. 58-59].

При анализе особенностей культурной коннотации, а точнее - культурнонациональной коннотации, мы будем исходить из постулата о том, что система образов, закрепленном в фразеологическом составе языка служит своего рода «нишей» для коммуляции, а потому может свидетельствовать о ее культурнонациональном опыте и традициях. Это положение служит исходной гипотезой исследования.

На основе этой гипотезы выдвигается и следующая гипотеза, так же лежащая в основе нашей концепции и связана с технологией воплощения культурной коннотации в содержание языкового знака: если единицы языка обладают культурно-национальной спецификой, то последняя должна иметь свои способы ее отображения и средства соотнесения с ней, т. е. служить своего рода «звеном», соединяющим в единую цепь «тело знака »- с одной стороны, а с другой - концепты, стереотипы, эталоны, символы, мифологемы и т. п. знаки национальной и шире - общечеловеческой культуры, освоенной народом носителем языка. 
Применительно к нашему материалу это означает, что если фразеологизм обладает культурно-национальной спецификой, то она должна по нашему мнению, иметь свое средство воплощения в их знаковую организацию и свой способ указания на эту специфику. Таким средством воплощения культурнонациональной специфики фразеологизмов служит образное основание (в том числе и включающее в себя культурно-маркированные реалии), а способом указания на эту специфику является интерпретация образного основания в знаковом культурно-национальном «пространстве» данного языкового сообщества. Такого рода интерпретация и составляет содержание культурнонациональной коннотации [1, с. 159].

Таким образом, понятие культурной коннотации является, с нашей точки зрения, базовым для лингвокультурологии - научной дисциплины, исследующей воплощенные в живой национальный язык материальную культуру и менталитет и проявляющиеся в языковых процессах в их действенной преемственности с языком и культурой этноса.

Тем самым мы считаем, что лингвокультурология призвана исследовать и описывать взаимодействие языка и культуры не только и не столько в ее этнических формах (которые привлекаются скорее как свидетельства преемственности культуры этноса и культуры национальностей), сколько в формах национальной и общечеловеческой культур в их современном состоянии или в определенные синхронные срезы этого взаимодействия. Под синхронными срезами здесь понимаются определенные периоды или эпохи жизни народа в целом или каких-либо его социальных групп, оказавших заметное воздействие на формирование ментальности народа.

Изложенное выше понимание предмета лингвокультурологии во многом наследует те плодотворные идеи, которые были высказаны в отечественной науке еще Покровским, Потебней. А затем Виноградовым, Лихачевым, Лотманом и которые так или иначе связаны с появлением культурнонациональной окраски образно-мотивационных средств языка [9, с. 214]. 
Лингвокультурология - это та часть этнолигвистики которая посвящена изучению и описанию корреспонденции языка и культуры в синхронном их взаимодействии. И ее глобальные задачи в основном совпадают с теми, которые были выдвинуты Н. И. Толстым при определении программы этнолингвистики того направления в языкознании, которое ориентирует исследования на рассмотрение соотношения и связи языка и духовной культуры, языка и народного менталитета, языка и народного творчества, их взаимозависимости и разного рода их корреспонденции» $[8$, с. 158$]$.

Естественно, что применительно к исторической ретроспективе и содержание культурной коннотации может быть определено только «в прошедшем времени» и по прошедшим до нас текстам. Тем самым этнолингвистика, как она сложилась к настоящему времени, развернута на категорию этноса и на реконструкцию его культуры по данным сохранившихся текстов, обычаев, ритуалов и т. п., из которых и извлекается «экстралингвистическая (культурная) коннотация» [2, с. 21], а лингвокультурология, как отмечено выше, исследует прежде всего живые коммуникативные процессы и связь используемых в них языковых выражений с синхронно действующим менталитетом народа.

Лингвокультурология в изложенном выше понимании ее задач наследует и ряд тех идей, которые были разработаны в русле континической, или рационалистической, теории языка [7, с.71], основные постулаты которой базируются на кумулятивной функции языка: если язык и отдельные его единицы могут служить средством накопления, хранения и средством внеязыковой информации, в том числе и культурно значимой, то, следовательно они могут рассматриваться как «вместилище знаний». Авторы называют эти знания фоновыми. Эти знания как бы навешиваются на лексему в виде «семантических долей» ее значения, а потому, по мнению авторов, доступны лингвистическому анализу и описанию. 
В этой теории усматривается предвосхищение когнитивного подхода к исследованию значения языковых единиц, хотя сами методы «навешивания» на них культурно значимой информации оперируют неформализованным процедурами ассоциативного восприятия «фона». Так, согласно этой теории, слово рожон, выступающее в роли компонента фразеологизма лезть (переть) на рожон, само по себе имеет, «семантическую долю», указывающую на ситуацию «русская охота на медведя», а ситуация соответствующая «буквальному» значению этого фразеологизма, является его прототипом [2, с.19].

Однако такой исторический или этимологический прием ввода культурнонациональной информации указывает лишь на исходную для образного основания этого фразеологизма ситуацию (прототип), выраженную в буквальном значении идиомы, лишь проясняют аналогию, лежащую в основе метафоры, но не эксплицирует культурно-национальной значимости собственно значения фразеологизма в живом его употреблении: как общее правило, «обычные» носители языка не владеют историко-этимологическим подтекстом значения фразеологизма. Экспликация культурно-национальной значимости фразеологизма достигается на основе рефлексивного - бессознательного или осознанного - соотнесения этого живого значение с теми «кодами» культуры, которые известны говорящему [10, с. 213].

Соотнесение языковых значений с тем или иным культурным кодом и составляет, с нашей точки зрения, содержание культурно-национальной коннотации, которая и придает культурно-значимую маркированность не только значениям фразеологизмов или слов, но и смыслу целых текстов.

Возвращаясь к страноведчески ориентированным описаниям соотношения языка и культуры, заметим, что они ставят своей целью выявить репертуар тех единиц язык, которые восходят к собственно национальным фактам материальной, социальной или духовной культуры как прототипам этих единиц языка с концептами общечеловеческой или национальной культуры. 
Установка страноведческих концептов скорее на исторический план фонового знания, нежели на синхронно-функциональное воплощение культурной «доли значения» в языковую сущность подтверждается и описанием материала в лингвострановедческом словаре «Русские фразеологизмы» под редакцией Е, М. Верещагина и В. Г. Костомарова [5, с. 111-112].

Культурно-национальное своеобразие фразеологизмов служит объектом изучения и близких к страноведческому направлению исследований, нацеленных на синхронное описание идиоэтнического различия во фразеологических составах разных языков (как родственных так и не родственных). Это сопоставительно е идиоэтническое направление исходит в основном из отслеживания в плане выражения фразеологизмов, близких по значению, различие в составе слов-компонентов, особенно культурномаркированных. Конечным итогом анализа и описания служит выявление собственно национального, равно как и универсального на уровне плана выражения, а также образной организации и ее концептуальных моделей.

Не случайно все работы этой ориентации вписывались в парадигму национально-культурного аспекта исследования где национальное - это прежде всего сам язык и его «этнонимы» (т.е. наименования обозначающие характерные для данного народа реалии - названия специфических орудий труда, вещей, собственных имен и т. п.), а культурное - это языковые образы в их соотнесении с характерами (а точнее - уникальными) для данного этноса ситуациями, историческими событиями и т. п.

Итогом такого сопоставления является описание наглядных различий в отборе слов-компонентов в качестве образной основы фразеологизмов, а следовательно - самих образов или их концептуальных моделей. Однако при этом «сердцевина» проблемы - в чем состоит связь фразеологизмов с менталитетом народа - не получила достаточно глубокого теоретического обоснования. 
Обычно исследования ограничивались констатацией различного для сравниваемых языков картирования мира средствами фразеологии и описанием фразеологических картин мира. В лучшем случае внимание обращалось и на наличие некоторого «промежуточного» мира - мира языковых образов, посредством которых национальное мировидение осуществляет «прорыв» в концептуальное освоение действительности [8, с. 191].

Следует еще раз обратить внимание на то, что при определении национально-культурной специфики за исходное принимается национальный язык в его идиоэтнических формах, а культурная значимость приписывается только такого рода языковому своеобразию.

Таким образом, лингвокультурологические исследования, посвященные культурно-национальному аспекту значения фразеологизмов, равно как и других языковых сущностей, должны включать в себя и сведения о характерологических чертах менталитета, содержание которых проявляется в культурной коннотации, которую мы считаем, как отмечалось выше, одним из базовых понятий лингвокультурологии.

Объект лингвокультурологии изучается на «перекрестке» двух фундаментальных наук: языкознания и культурологии. Последняя использует такой атрибут человека, как его самосознание по отношению к природе, обществу, истории, науке, религии, искусству и т.п. сферам его материального, социального и духовного бытия, в которых протекает и осуществляется обретение идентичности своего «человеческого» Я с культурой народа или человечества в целом путем создания, отбора и присвоения тех или иных ценностно значимых для этого ориентиров в качестве мотивов человеческой жизнедеятельности [9, с. 102].

Таким образом, лингвокультурология ориентирована на человеческий, а точнее - на культурный фактор в языке и на языковой фактор в человеке. А это значит, что лингвокультурология - достояние собственно антропологической 
парадигмы науки о человеке, центром притяжения которой является феномен культуры [6, с.34].

Для лингвокультурологического анализа, оперирующего культурнонациональной коннотацией, понятие культуры является базовым, поэтому мы считаем необходимым хотя бы в самых общих чертах остановиться на ее онтологических признаках, главным из которых является для нашей темы ее семиотический характер.

Культура, если отвлечься от истории ее определения сначала в противопоставлении природе и выделившегося из нее в процессах цивилизации человека, затем на основе таких онтологических ее свойств, как эволюционный характер, ценностная ориентация, отраженная в жизненной философии народа, ее историзм, межпоколенная трансляция на основе групповых традиций, кроющихся в коллективном бессознательном и т.п. - это мировидение и миропонимание, обладающее семиотической природой [6, с. 34-35].

Таким образом, коннотация, как показывает анализ традиционнопоэтической лексики и фразеологии, есть один из способов хранения культурной информации. 


\section{Литература:}

1. Апресян Ю. Д. Коннотации как часть прагматики слова // Избранные труды. М., 1995. Т. 2. С. 159.

2. Бабенко Л. Г. Русская эмотивная лексика как функциональная система. Свердловск, 1989. С. 21.

3. Винокур Г. О. О языке художественной литературы / сост. Т.Г. Винокур. М., 1991. С. 241.

4. Говердовский В. И. История понятия коннотации // Филологические науки. 1979. $\mathrm{N}^{\circ} 1$.

5. Матвеева Т. В. Коннотация // Матвеева Т.В. Учебный словарь: русский язык, культура речи, стилистика, риторика. М., 2003. С. 111-112.

6. Опарина Е. О. Лингвокультурология: методологические основания и базовые понятия // Язык и культура: сб. обзоров. М., 1999. Вып. 2. С. 34-35.

7. Сапожникова О. С. К семантической систематизации коннотативных значений // Филологические науки. 2003. № 2. С. 71.

8. Телия В. Н. Метафоризация и ее роль в создании языковой картины мира // Роль человеческого фактора в языке. М., 1988. С. 199.

9. Телия В. Н. Коннотативный аспект семантики номинативных единиц. M., 1986. C. 214.

10. Телия В. Н. Русская фразеология: семантический, прагматический и лингвокультурологический аспекты. М., 1996. С. 215.

11. Токарев Г. В. К вопросу о типологии культурных коннотаций // Филологические науки. 2003. № 3. С. 58-59. 